\title{
Implementing Direct Instruction in the Teaching and Learning Instrument Development Course
}

\author{
Subandi \\ Universitas Negeri Surabaya \\ Surabaya, Indonesia \\ subandi@unesa.ac.id \\ Cicik Arista \\ Universitas Negeri Surabaya \\ Surabaya, Indonesia \\ cicikarista@unesa.ac.id
}

\author{
Muhammad Farhan Masrur \\ Universitas Negeri Surabaya \\ Surabaya, Indonesia \\ feng_feilun27@yahoo.com \\ Rendy Aditya \\ Universitas Negeri Surabaya \\ Surabaya, Indonesia \\ aditya_frenz11@yahoo.com
}

\begin{abstract}
Student's competence formation in the world of education is a common problem that occurs at every level and all education promoters. The direct instruction can be used as an alternative solution in the learning process to overcome these problems. The direct instruction is proven to be able to help students to understand the knowledge easier that is characterized by the formation of skills in preparing the lesson plans because this model provides the opportunity for students to experience directly about the process of preparing the required learning tools. The gained direct experience is stored in the memory which is continued by the deposition process then will become a semipermanent knowledge. With the deposition of experience in an activity that is experienced directly, it can make students easier to get back the knowledge from memory when needed. Therefore, based on the results of this study, the direct instruction is considered feasible to be used as an alternative choice, especially in the teaching and learning process usage that has the goal of forming the skills in developing learning tools for students. Because this type of learning model is more aimed at the formation of abilities and skills in students in which students are required to produce a device and not just test pedagogical knowledge at the end of the learning process.
\end{abstract}

Keywords-direct instruction, construction, direct experience, demonstration, declarative

\section{INTRODUCTION}

Learning is an activity that involves students with a variety of characters and motivational background which are complex and dynamic. With various complexities of the students' condition, education has the task not only to form the competency of cognitive aspects but also to form the psychomotor aspects as indicators of the positive behaviour formation through the learning process. Learning is a form of developing a scientific concept activity that is used as a source of changes in behaviours, attitudes, and paradigms of students [1]. That means the educational process has a fairly basic task which is changing and forming the behaviour and character of the students that more reflects as educated behaviour and character characterized by knowledge and skills aspect. In addition, Iskandarwassid [2] explained that the learning process is a process of behavior change through interactions between the individual and the environment where he lives and as a series of activities that are sustainable, planned, gradual, alternating, balanced, and integrated. This strengthens the opinion that the changes of behavior and mindset in individual students are a result of a continuous and planned learning process in order to obtain an overall improvement in the quality of students' life such as cognitive aspects, especially those which are concerning intellectual, skills and other values in students themselves. Also, it is stated by Aljunied \& Poon [3] that education must ultimately be able to bring students to the ability to interact socially, communicate socially also have the attention towards attitudes, behavior and lead to an easier and more meaningful life. Therefore, the application accuracy of learning models is one of the most important factors in order to achieve ideal learning outcomes.

Direct instruction is a learning model that is more referring students to build understanding through direct experience in the form of practice or direct demonstrations. This direct instruction has been applied to study program students. Mandarin Language Education of Faculty of Language and Art in a particular university of Surabaya, class of 2016/2017, who are currently taking a learning subject that is the Development of Learning Media in order to form knowledge and skills in developing lesson plans also to prepare the university students who are going to do their teaching internship in the school. In the first stage, the university students have not understood well both in theoretical knowledge and skills in preparing the lesson plan. Lesson plan is a learning tool that has a very vital and fundamental role especially for future teachers or beginner teachers [4]. Because the characteristics of this subject are more demanding the students ability to produce products in the form of lesson plan as the final target of learning; therefore, an approach that is chosen and considered appropriate to use is a learning model that emphasize the university students to conduct the demonstration or practice directly meanwhile the theoretical knowledge aspect is used as an introduction and is strengthened when the university students do the practice, a presentation, and discussions. By providing more 
opportunities for the university students to experience in developing lesson plans directly then they will be able to find out the knowledge which is taught in real, therefore, it can facilitate the university students in constructing their understanding. As stated by Glogger [5] and Naeimi [6], students can set and design the understanding with the direct instruction in which this aspect becomes more important in the process of understanding a concept. Moreover, Kozloff [7], and Oladayo [8] mentioned that the direct instruction can stimulate students for being active in the process of presenting ideas and even in responding criticism based on their experiences. That means university students tend to be active through the direct instruction so it gives freedom to design and construct the process of understanding in accordance with what they experienced. Basically, it is because one of the objectives of organizing the educational process that is the improvement of students' thinking ability (in the case of university students) on a concept of knowledge also the students must be able to actualize the concept in the form of more concrete results.

\section{A. Direct instruction and the Roles}

A direct learner is a learning model that provides a direct experience to students through modelling, practical work, and both demonstration and presentation in order to facilitate the students' understanding of the concept. The direct instruction is designed to introduce the students toward the learning subjects for building their interests, curiosity, and stimulating them to think independently in order to find understanding of certain concepts and skills independently as well. As Schug (2001: 49) [9], and Stevick (1976: 16) [10] mentioned, the direct instruction is developed specifically for improving the students' learning process especially in understanding a knowledge. Also, it fully explains according to procedural knowledge and declarative knowledge that is taught in stages. It is strengthed by Arends's opinion [11] that direct instruction is one of the teaching model which is specifically designed to develop student learning about the prosedural and declarative knowledge which are well structured and can be learned in stages or step by step. From the two quotations, it can be concluded that basically the direct instruction aims to provide students with a gradual process of understanding the concept. Therefore, teachers who want to use the direct instruction must identify learning objectives, material structure, and basic skills which are going to be taught. Next, the basic knowledge that is more theoretical explained to the students then the teacher gives a demonstration also an opportunity to the students for practicing their skills that learned and giving feedback. The direct instruction has three general characteristics, those are:

a. There are learning objectives and the influence of models on students including learning assessment procedures.

b. Syntax or the overall pattern and the flow of learning activities.

c. Management system and learning environment model are neede for certain learning activities to implement
successfully.First, confirm that you have the correct template for your paper size.

This learning model is used to describe the learning model in a face-to-face context and it has been designed to improve the students' behaviour; moreover, it is sought by teachers to monitor and control the attention and participation of students in the classroom [12]. This opinion indicates that the students' behaviour and their changes in the learning process is an aspect that is made the focus of the direct instruction. Furthermore, it is more prioritize the process aspect especially students' active role and their behaviour during the learning process and not only the final outcome of learning. Therefore, the students are required to learn a basic skill and get information that is able to be taught gradually. The direct instruction also gives students the opportunity to observe selectively, remembering, and imitating what the teacher modelled. In addition, the direct instruction also prioritizes a declarative approach with a focus on the process of learning concepts and motoric skills, so that the learning atmosphere can be more interesting and structured. Next, Lee and Anderson [13] mentioned that the students will be competent and responsive to every symptom and phenomenon also it will be easy to convey students' opinions as a result of the authority to manage the understanding concept. Moreover, Schwartz et al [14] mentioned that if the students have their own way to manage themselves, it affects students' psychology which there is no much pressure on them and positively learners will feel they have strength and ability. Both of the quotations above can be interpreted that the direct instruction has a role not only on one aspect of the learning target but also giving a positive impact on students' psychology condition. The psychology condition of students has very significant relevance to the smooth implementation of the learning process and the achievement of learning objectives. Comfortable psychological conditions without any pressure and attraction towards the learning model have a higher possibility to achieve learning goals than psychological conditions that are depressed and due to compulsion [15]. As stated by Gagne [16], aspects of students' interest in a learning model can greatly support the achievement of learning objectives. The opinion above can be interpreted that learning approach models, that are interesting for students, will be able to motivate students which will ultimately be able to facilitate students to understand learning materials. The learning mode that gives the students to manage their own learning process is considered more interesting. It is because the students relatively will be able to be more active in doing relevance activities in order to build knowledge, skills, and setting that related to learning targets and objectives. This opinion is strengthened by Magliaro et al [17], Mesquita [18], and Metzler [19] which the point is mentioning the basic aims of the direct instruction, those are to provide direct experience to the students so that in the next stage they can carry out independently by using the experience gained by experiencing themselves. Next, Gunawan [20] delivered that there is no words, nor sentences which are stored directly in the human brain, but they will be connected easier with imaginations, attitudes or the events experienced directly, events, colours, symbols, and suchlike that is easy to be remembered. Two opinions above emphasis that the human brain is more 
sensitive to real and concrete stimuli such as events or events that are experienced directly so that it will be easier to express again than things that are abstract like a concept. This is because things that are concrete and real that can be enjoyed by the sense of sight are easier to remember in the memory of the human brain. In contrast, words in which the physical existence is invisible and more abstract; in consequence, it is more difficult to remember.

The experience that obtained directly has suitability with the action mechanism of the human brain. The human brain will be more interested then the next respond will be remembered for all objects that are interesting sympathetic and concrete. As delivered by Buzan [21], the human brain has a motivation and interest toward all data/objects that interesting and concrete so that brain performance is easy and fast in the form of responding to the data which is accepted. By using the concrete experience and knowledge, at least, they can engage the students' interests and the direct instruction can fulfill the tastes and needs of the human brain character. It is because these suitability factors stimulate the human brain for receiving and saving the objects/data so that it is able to remember and reveal again. Also, It is strengthened by Buzan [22] that something that is known will be remembered and in a relatively short time, it will be revealed soon. This indicates that the human brain is making preparations to input new information. The mechanism of action as mentioned above indicates that the direct instruction has harmony with the character of the human brain. Technical presentation of mechanisms, procedures, and stages help facilitate the work of the brain in order to find and reveal in sequence, coherently, and thoroughly so these form a systematic sequence. The five syntaxes of Lee and Anderson's direct instruction are as follows (see also Trianto [23] and Kardi and Nur [24]).

TABLE I.

SYNTAX OF DIRECT INSTRUCTION

\begin{tabular}{|c|c|}
\hline Phase & Teachers' Role \\
\hline $\begin{array}{l}\text { Phase I } \\
\text { Deliver goals and preparing students. }\end{array}$ & $\begin{array}{l}\text { Explain the learning objectives, } \\
\text { background information of the } \\
\text { lesson, prepare students to learn. }\end{array}$ \\
\hline $\begin{array}{l}\text { Phase II } \\
\text { Demonstrate the knowledge or skills }\end{array}$ & $\begin{array}{l}\text { Demonstrate skills correctly or } \\
\text { present information step by step. }\end{array}$ \\
\hline $\begin{array}{c}\text { Phase III } \\
\text { Guide a training }\end{array}$ & $\begin{array}{l}\text { Plan and provide initial guidance } \\
\text { and training. }\end{array}$ \\
\hline $\begin{array}{l}\text { Phase IV } \\
\text { Check the understanding and provide a } \\
\text { feedback }\end{array}$ & $\begin{array}{l}\text { Check whether students have done } \\
\text { the task well then give a feedback. }\end{array}$ \\
\hline $\begin{array}{l}\text { Phase V } \\
\text { Provide opportunities for } \\
\text { independent training. }\end{array}$ & $\begin{array}{l}\text { Give assignments to students to } \\
\text { apply the skills that they have just } \\
\text { acquired independently. }\end{array}$ \\
\hline
\end{tabular}

\section{METHODS}

Participants in this study were 38 students in the fifth semester in Mandarin education program, in a particular university of Surabaya. They are programming or taking the Teaching Instrument Development subject and are divided into 6 big groups. This research is done within one semester (15 meetings) with the following classification: 4 meetings of discussing the theoretical concepts, 3 meetings of discussing technique and procedure for elaborating $\mathrm{KD}$ into indicators, determining materials according to indicators, determining forms of learning, determining methods/approaches and media and determining tools and forms of assessment according to the character of the material preparation guidance, 2 meetings of RPP preparation process, and 6 final meetings of presenting, discation and reflecting the project. The data is in form of observation result toward the students' performances in the accuracy of the elaboration and linearity of KD to the indicator, the suitability of the indicator with the material, the suitability of the material with the learning method/approach, the form of learning, and the appropriateness of the media used, and the appropriateness of the tools and forms of assessment. The approach used was learning approach which has developed by Matoba [25], Fernandez [26], and Dotger [27] as depicted in the Figure 1 as in the following:

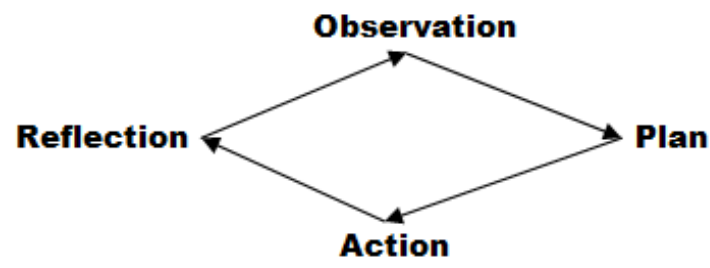

Fig. 1. The Concepts of Study

Based on the type and form of data, the technique data analysis used is in form of descriptive analysis. It describes the phenomenon, action and any events that happen in every research data in each cycle.

\section{RESUlTS AND DISCUSSION}

\section{A. Cycle 1}

\section{1) KD Elaboration into Indicators}

The data analyzed at this stage are the results of the mentoring work 3 times face-to-face and the results before being presented. Based on the observations in the initial draft of the lesson plan that has been prepared by students, especially in the aspects of KD and indicators, there are still a majority of students in each group who do not fully understand the procedure related to the elaboration of $\mathrm{KD}$ into indicators. This is proven by many indicators that have been broken down from the KD that are not appropriate or not fully linear with the competencies recommended in the KD. The nonlinearity occurs as though less operational editorials, such as the use of the term 'understanding' which has not led to concrete operational editors yet; as a result, the competencies that are going to be achieved in the formulation of indicators are not concrete yet and cannot be measured. In addition, there is also an incompatibility between competency demands in $\mathrm{KD}$ with indicator formulations. For example, in the $\mathrm{KD}$, it is required to achieve the competence of conveying daily activities; however, the formulation of indicators compiled more emphasizes on the competence of reading and writing Chinese, hanzi, Chinese language characters. Based on the demands of the core competencies in $\mathrm{KD}$, competence in reading and writing alphabets has been completed or included in the previous KD. Therefore, researchers conducted training 
and reassessment of the mechanism and steps of formulating indicators based on the $\mathrm{KD}$ in an intense manner to each group. At the first stage, the researcher provides training on identifying core competencies that must be achieved in the KD. Furthermore, as a demonstration of practical work, each group was asked to identify the core competencies in class $\mathrm{X}$ of the $\mathrm{KD}$ according to the themes of each group that had been set. After the core competencies are identified, the technical formulation of the indicators is shown. During the group work, the researchers went around and alternately gave direct guidance to each group that was experiencing difficulties. The researcher's response to questions of each group that is conveyed classically as a form of discussion in order to help all students know the problems experienced by one group, then it can be ways and strategies of resolution for other groups. Therefore, when other groups get the same problem, it is expected to be able to resolve the problem independently.

Then, every group presented the results of the group work in turn as a material for joint discussion and evaluation between groups with time allocation 15 minutes of presentation of work results, 30 minutes of discussion, and 5 minutes of concluding. From the work results of each group, they have improved in general. The main types of competencies that is presented in indicators are mostly linear with the $\mathrm{KD}$ and the description that is also more concrete (as in Figure 1a and 1b). The improvements proposal that can be given by researchers in overall; those are, aspects that may be added in the formulation of indicators to complement the indicators that have been prepared by each group. This is intended to all competencies that are the focus and demands in the KD can be implemented through the learning process and can be measured at the end of learning.

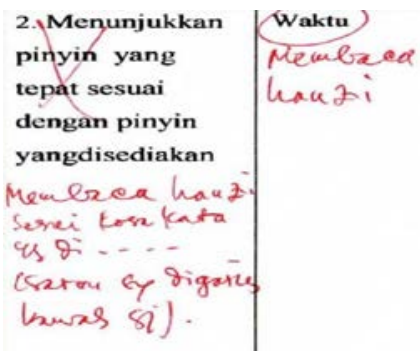

Fig. 2a. Draft before revising

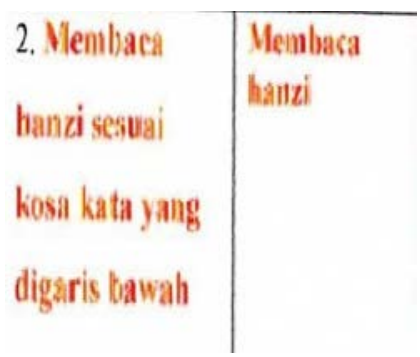

Fig. 2b. Draft after revising
At the same time, the discussion stage evaluates the overall group work results and they are used as a basis for improvement (see also Mayer, [28]). At the discussion stage, observations were made with the participants and the presenter groups. In terms of participants in general, all groups responded in the form of both questions and input. This indicates that even though the theme is presented by the presenter group is different from the theme that worked by the questioner group, it can be followed by other participant groups. The questions given are not only questions due to the incomprehension of the questioning group but it tend to the confirmation based on the questioner's argument. So that, the discussion and argument between the presenter group and the questioner group ensues. Participants complete the components that are formulated by the presenter group by providing the proposals/inputs. Both of these things indicate that on the part of the participants there has been a form of understanding of the technical and procedures for elaborating $\mathrm{KD}$ into indicators. The contents of the questions and input submitted by the participants have shown suitability both from the aspect of the mechanism and the suitability of the theme discussed by the presenter group. This condition proves that the participants' understanding is not only limited to the themes that are worked by each group, but it is a general and standardized understanding of the mechanism. Observations to the presenter group including a mastery of the material at the time of presentation, systematic presentation (the aspects of linking), and mastery of the material shown when giving answers to questions or input from other groups. Students have mastered the material including stages, technical, mechanism, and relevance between components in the aspects of mastery of the material in general. The stages and technicalities that were passed during breaking down the KD were already correct, that is, from identifying the main competencies that were required in the $\mathrm{KD}$ then it was outlined in the indicator. The mechanism which is used to formulate the indicators has met the standards because based on the indicators formulation, it can be captured the competencies that are going to be achieved. The indicator formulation has a relationship and a sequence of indicators between one indicator and the next so that it provides a systematic and continuous picture. The conclusion on students' mastery is getting stronger when the students are able to provide answers with clear and concrete explanations. The most significant response when one of the groups responded to the question, "How can your group determine the achievement of competence with the Chinese cultural songs and festivals even though there are no such themes and materials in the textbook?" The answer given by the presenter group is, "We determine the achievement of students' competencies not based on the availability of themes and material in textbooks. So, it is based on the KD that has been established in the curriculum, therefore, our reference when compiling planning tools is the curriculum". Based on the response, it gives reinforcement that students have understood that in order to compile the lesson plan, they must see and use the KD that is in the curriculum as a reference and not based on textbooks. In addition, all presenter groups have been able to provide responses both questions and inputs that are quite 
good. If there are some additions, it is just to complete and to clarify them.

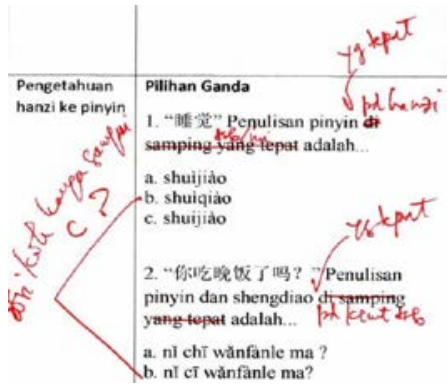

Fig. 3a. Draft before revising

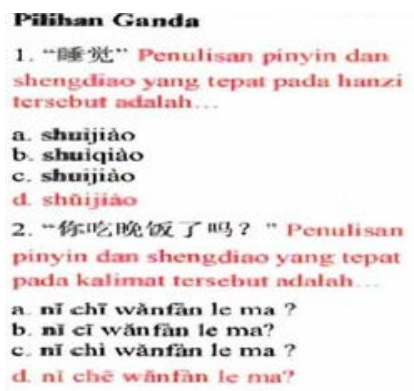

Fig. 3b. Draft after revising

\section{B. Cycle II}

The cycle II is more focused on the university students' skills in implementing the indicators into the material, determine the form and method or approach of learning, learning media, and assessment. The results are, there are two problems faced by students in general, namely, the incompatibility of the type of material planned with the demands of the main competency of the indicators also the incompatibility between the indicators with the type and form of assessment tools. Whereas in determining the method/approach and the supporting media, there are only inputs for improvement, fortunately, there are no significant problems.

The incompatibility between indicators and material still occurs in almost all groups. Students seem unable to realize the description of the main competencies that have been compiled in the indicators formulation to the suitable and appropriate type of material. For example, in the indicator formulation shows, "students say greetings that are used in everyday life" but the substance of the planned material is "say vocabularies according to the right tone (sengdiao)". The indicators have already required students at the stage of communication skills but the material is still planned to form theoretical skills. This was seen when the researcher explained the main competency demands of one indicator that has been compiled by one of the groups, it still had to re-explain and showed the form and type of skills that must be achieved concretely on the indicator. After that, the researcher had to show examples, form and kinds of material that are suitable in order to achieve one of those skills. Due to the better understanding, the researcher took randomly one indicator for each group as training and guidance material. Thus, during the training, the researcher was only at an early stage that fully involved in the process of determining the skills and types of suitable material. The researcher gradually asked students who determine the type of skills by giving questions such as, "what can students do?" At the stage of determining the material, the researcher also provided guidance with provoking strategies through questions such as, "so that students can do this, what should we teach them?", "In order to do this... so the students must know about what?" and so on. Then, in the final stage, students were asked to arrange their own way based on the formulation of other indicators that have not been discussed. From the results of mentoring in this phase, it seems that there have been very significant improvements. In the aspect of the drafting process, there were almost no questions or difficulties from all groups and also no fundamental problems or errors were found, all results from all groups were included in the sufficient category.

Because in the preparation process has been done the assistance, training, and stabilization in practical work or direct demonstration, therefore, a draft of the lesson plans can be produced well also can contribute to the presentation and discussion of all groups that are already quite good. All groups can convey a flow chart of stages and the mechanism of compilation in a coherent, continuous and fulfilling linearity aspect. Other groups that act as participants as well as researchers who also act as observers are also able to understand and provide good input so that it is useful to improve and complete the draft which is prepared by the presenter group. The presenter's answers during the Question and Answer section are also well structured in detail and already fulfill relevance aspects. This illustrates the understanding and mastery of the presenter group on the material presented is already good.

The conclusion above is supported by the results of the student response in the questionnaire that is given at the end of face-to-face learning. The questions on the questionnaire are divided into 3 categories, those are, the first question related to the impression of the application of the direct instruction. The results are 37 or $97.3 \%$ of the total number of students who feel the direct instruction is easy to follow and is considered to use with the characteristics of productive subjects. The second question is about the role of the direct instruction in the process of understanding and increasing student activity. The results are 36 or $94.7 \%$ of students who feel that the direct instruction is very helpful and they find it easier to understand the material also the mechanism of work so that students can enjoy, feel comfortable. Then, this understanding contributes positively to the student activity improvement during the learning process. Through the direct instruction, students have gained experiences during demonstrations and group practice work then get to stabilize during the discussion of the presentation of the results. Next, the third question is talking about acquisition of input and opinions related to the reason why this direct instruction is good to be applied. The result is 37 of 38 students stated that the direct instruction is necessary to be used because by using this model, the students are maximally more focused on the process of forming the understanding structure and skills through direct experience that can strengthen the material mastery. The students also suggest to prioritize the demonstration process and the practical work in the direct 
instruction due to students find them easier to apply theoretical concepts that have been accepted at an early stage, so that understanding and mastery of the material is more concrete and real

\section{CONCLUSION}

Through the direct learning, students can get real experiences through a guided demonstration and direct independent practical work. Direct experiences are forming learners' understanding to be more concrete and real which eventually form synergistic knowledge and skills to produce a product that is targeted at basic competencies, namely the lesson plan. Students' knowledge and skills are built through each stage of the learning process so that the development of competencies can be controlled and evaluated periodically and thoroughly. The competence improvement can be measured based on the results of each stage in every process that is marked with the increasing improvement. This result is also strengthened by the participants' responds which are approximately $96 \%$ of the direct instruction usage is giving a positive contribution on the understanding process and the formation of skills in developing lesson plans. The experience gained from the direct preparation process during the practical work that is considered as a phase of strengthening and stabilizing knowledge and skills.

\section{REFERENCES}

[1] Subandi, et al., "The Implementation of Mind Mapping Technique to Improve Mandarin Students' Systematic Thinking Skills,” In Advances in Social Science, Education and Humanities Research, Atlantis Press, Volume. 222, 2018, pp.390-395

[2] Iskandarwassid, and D. Sunendar, Strategi Belajar Bahasa. Bandung: Remaja Rosdakarya Offset, 2009.

[3] Aljunied, Mariam, and K.K. Poon, Thinking and Learning Characteristics. In: Poon, Keneneth K. Educating Students With Autism Spectrum Disorders -Making Schools Meaningful-. Jurong Singapore: Pearson, 2009.

[4] N. Maynes, and B.E. Hatt, "Two Ways to Teach: Direct Instruction and Indirect Instruction/Inquiry: Simplifying Planning Concepts for Early Career Teachers,” Journal of Studies in Education, Vol. 6, No. 3, 2016, pp.113-123.

[5] Glogger-Frey, Inga, K. Gaus, and A. Renki, "Learning from Direct Instruction: Best Prepared by Several Self-Regulated or Guided Invention Activities?” ELSEVIER, Learning and Instruction XXX, 2016, pp.1-10

[6] M. Naeimi, and T. Chow Voon Foo, "Vocabulary Acquisition through Direct and Indirect Learning Strategies,” English Language Teaching, 8 (10), 2015, pp.140-150.

[7] Kozloff, A. Martin, and L. LaNunziate, "Direct Instruction in Education,” University of North Carolina at Wilmington, pp. 1-26, January 1999.

[8] O.T. Oladayo, and C.F. Oladayo, "Effects of Direct and Indirect Instructional Strategies on Students' Achievement in Mathematics,” An International Multidisciplinary Journal, Vol. 6 (4), Serial No. 27, pp.349-361, October 2012.
[9] C. Schug, M, G. T. Sara, and D. W. Richard, "Direct Instruction and The Teaching of Early Reading, Wisconsin's Teacher-led Insurgency, Wisconsin Policy Research Institute,” INC, 2001.

[10] E. Stevick, Memory, Meaning, and Method. Rowley, MA: Newbury House, 1976.

[11] Arends, and I. Richard, Learning to Teach: $9^{\text {th }}$ Edition. New York. McGraw-Hill, 2012.

[12] Magliaro, G. Susan, B.B. Lockee, and J.K. Burton, "Direct Instruction Revisited: A Key Model for Instructional Technology,” In Educational Technology Research and Development, pp.41-55, January 2005.

[13] S. Lee, T. Graham, and H.W. Stevenson, "Teachers and Teaching: Elementary Schools in Japan and The United States," Teaching and Learning in Japan, edited by Thomas P. Rohlen \& Gerald K. Le Tendre, Cambridge University Press, 1996, pp.177.

[14] D.L. Schwartz, C.C. Chase, M.A. Oppezzo, and D.B. Chin, "Practicing Versus Inventing with Contrasting Cases: The Effects of Telling First on Learning and Transfer," Journal of Educational Psycology, 103, 2011, pp.759-775.

[15] W. Sanjaya, Strategi Pembelajaran Berorientasi Standar Proses Pendidikan. Jakarta: Kencana, 2007.

[16] Gagne, M. Robert, and L.J. Briggs, Principles of Instructional Design. Florida State University, 1979.

[17] Magliaro, G. Susan, B.B. Lockee, and J.K. Burton, "Direct Instruction Revisited: A Key Model for Instructional Technology,” In Educational Technology Research and Development, pp.41-55, January 2005.

[18] I. Mesquita, P. Coutinho, "The Value of Indirect Teaching Strategies in Enhancing Student-Coaches' Learning Engagement," Journal of Sports Science and Medicine, pp.657-668, September 2015

[19] M. Metzler, Instructional Models for Physical Education. Allyn and Bacon, Needham Heights, 2000

[20] A.W. Gunawan, Genius Learning Strategy Petunjuk Praktis untuk Menerapkan Accelerated Learning. Jakarta: Gramedia, 2007.

[21] T. Buzan, and B. Buzan, 「ザ・マインドマップ」一脳の 無限の可能性を引き出す技術一東京 : ダイヤモンド, 2013.

[22] Buzan, Toni. 「マインドマップ読書術」Translated by 近田美季子。 東京 : ディスカヴァー・トウエンティワン, 2009.

[23] Trianto. Mendesain Model Pembelajaran Inovatif-progresif: Konsep, Landasan dan Implementasinya pada Kurikulum Tingkat Satuan Pendidik (KTSP). Kencana Prenada Media Group, 2011.

[24] Kardi and Nur. Pembelajaran Langsung. Surabaya: Universitas Negeri Surabaya, 2000

[25] M. Matoba, "Jugyoukiroku no Saikousei to Jugyoushoyouin no Shucchou ni Kan Suru Jikken Kenkyuu,” Nagoya Daigaku Daigakuin Kyouiku Hattatsukagaku Kenkyuukakiyou, Vol. 3, 2008, pp.148-161.

[26] C. Fernandez. "Learning from Japanese Approaches to Proffesiona Development: The Case of Lesson Study," Journal of Teacher Education, 53 (5), 2002, pp.393-405.

[27] S. Dotger, "Methodological Understandings from Elementary Science Lesson Study Facilitation and Research,” J Sci Teacher Educ, 26, 2015, pp.349-369

[28] L. Mayer, R. Gersten, and J. Gutkin, "Direct Instruction: A Projec Follow Through Success Story in an Inner-city School," Elementary School Journal, 84, 1983, 241-252. 